\title{
Simplexins A-I, Eunicellin-Based Diterpenoids from the Soft Coral Klyxum simplex
}

\author{
Shwu-Li Wu, ${ }^{\dagger}{ }^{\ddagger}$ Jui-Hsin Su, ${ }^{\S}$ Zhi-Hong Wen, ${ }^{\dagger}$ Chi-Hsin Hsu, ${ }^{\dagger}$ Bo-Wei Chen, ${ }^{\dagger}$ Chang-Feng Dai, ${ }^{\perp}$ Yao-Haur Kuo," and \\ Jyh-Horng Sheu $* \dagger, \nabla$ \\ Department of Marine Biotechnology and Resources, National Sun Yat-sen University, Kaohsiung 804, Taiwan, Republic of China, Center of \\ General Studies, National Kaohsiung Marine University, Kaohsiung 811, Taiwan, Republic of China, Department of Biological Science and \\ Technology, Mei-Ho Institute of Technology, 23 Ping Kuang Road, Neipu Hsiang, Pingtung 912, Taiwan, Republic of China, Institute of \\ Oceanography, National Taiwan University, Taipei 112, Taiwan, Republic of China, National Research Institute of Chinese Medicine, \\ Taipei 112, Taiwan, Republic of China, and Asia-Pacific Ocean Research Center, National Sun Yat-sen University, \\ Kaohsiung 804, Taiwan, Republic of China
}

Received February 9, 2009

\begin{abstract}
Nine new eunicellin-based diterpenoids, simplexins A-I (1-9), were isolated from a Dongsha Atoll soft coral, Klyxum simplex. The structures of these compounds were established by detailed spectroscopic analysis (IR, MS, 1D and 2D NMR) and by comparison with the physical and spectral data of related known compounds. The absolute configuration of $\mathbf{1}$ was determined by a modified Mosher's method. Compounds $\mathbf{1 ,} \mathbf{4}$, and $\mathbf{5}$ were found to be cytotoxic toward a limited panel of cancer cell lines. Compound $\mathbf{5}$ was shown to significantly inhibit the accumulation of the pro-inflammatory iNOS and COX-2 proteins in LPS-stimulated RAW264.7 macrophage cells.
\end{abstract}

The first eunicellin-based diterpenoid was isolated from the Mediterranean gorgonian Eunicella singularis in $1968 .{ }^{1}$ Since then, many eunicellin-based diterpenoids were isolated from various marine organisms, and some of these metabolites were shown to possess interesting biological activities (e.g., anti-inflammatory, ${ }^{2}$ cytotoxic, ${ }^{3-10}$ inhibition of cell division of fertilized starfish eggs, ${ }^{11}$ hemolytic activity, ${ }^{12}$ antiplasmodial activity against chloroquineresistant Plasmodium falciparum W2, and antituberculosis activity against Mycobacterium tuberculosis $\mathrm{H}_{37}-\mathrm{Rv}^{13}$ ). We have previously isolated several eunicellin-based diterpenoids, named australins $\mathrm{A}-\mathrm{D},{ }^{4}$ vigulariol, ${ }^{8}$ and pachyclavulariaenones $\mathrm{A}-\mathrm{G},{ }^{10,14}$ from soft corals. Our study on the chemical constituents of a Dongsha Atoll soft coral, Klyxum simplex Thomson and Dean (phylum Cnidaria, class Anthozoa, order Alcyonacea, family Alcyoniidae), has yielded nine new eunicellin-based diterpenoids, simplexins A-I (1-9). These compounds possess the more common C-2, C-9-ether linkage, characteristic of the eunicellin-based diterpenoids. The molecular structures of these compounds, including their relative configurations, were established by detailed spectroscopic analysis and by comparison with the physical and spectroscopic data of related known compounds. The absolute structure of $\mathbf{1}$ was determined by using a modified Mosher's method. The cytotoxicity of compounds 1-9 against human medulloblastoma (Daoy), human breast carcinoma (MCF-7), human cervical epitheloid (HeLa), and human laryngeal (Hep 2) carcinoma cells was studied, and the ability of 1-6 and 9 to inhibit up-regulation of the pro-inflammatory iNOS (inducible nitric oxide synthase) and COX-2 (cyclooxygenase-2) proteins in LPS (lipopolysaccharide)-stimulated RAW264.7 macrophage cells was also evaluated.

\section{Results and Discussion}

Simplexin A (1) was obtained as a colorless oil. The HRESIMS $\left(\mathrm{m} / \mathrm{z}, 473.2879[\mathrm{M}+\mathrm{Na}]^{+}\right)$of $\mathbf{1}$ established a molecular formula of $\mathrm{C}_{26} \mathrm{H}_{42} \mathrm{O}_{6} \mathrm{Na}$, appropriate for six degrees of unsaturation. The

* To whom correspondence should be addressed. Tel: 886-7-5252000, ext. 5030. Fax: 886-7-5255020. E-mail: sheu@mail.nsysu.edu.tw.

'Department of Marine Biotechnology and Resources, National Sun Yatsen University.

$\stackrel{*}{*}$ National Kaohsiung Marine University.

$\S$ Mei-Ho Institute of Technology.

${ }^{\perp}$ National Taiwan University.

"National Research Institute of Chinese Medicine.

$\nabla$ Asia-Pacific Ocean Research Center, National Sun Yat-sen University.
IR absorptions at $v_{\max } 3432$ (broad) and $1723 \mathrm{~cm}^{-1}$ revealed the presence of hydroxy and carbonyl functionalities. The ${ }^{13} \mathrm{C} \mathrm{NMR}$ spectrum measured in $\mathrm{CDCl}_{3}$ showed signals of 26 carbons (Table 1), which were assigned by the assistance of the DEPT spectrum to six methyls, eight methylenes, seven methines (including three oxymethines), two carbonyls, two $\mathrm{sp}^{2}$ oxygenated quaternary carbons, and one $\mathrm{sp}^{2}$ quaternary carbon of an olefinic group. The NMR spectroscopic data of $\mathbf{1}$ (Tables 1 and 3 ) showed the appearance of a 1,1-disubstituted double bond $\left(\delta_{\mathrm{C}} 116.8, \mathrm{CH}_{2}\right.$ and $150.3, \mathrm{qC} ; \delta_{\mathrm{H}} 5.21, \mathrm{~s}$ and $\left.5.47, \mathrm{~s}\right)$. The presence of one acetoxy group was indicated by the ${ }^{1} \mathrm{H}$ NMR signal at $\delta 2.01(\mathrm{~s}, 3 \mathrm{H})$ and ${ }^{13} \mathrm{C} \mathrm{NMR}$ signals at $\delta 22.5\left(\mathrm{CH}_{3}\right)$ and 170.1 (qC) in compound 1 . In addition, the ${ }^{1} \mathrm{H}$ NMR spectroscopic data of $\mathbf{1}$ showed the presence of one $n$-butyryloxy moiety, which shows signals at $\delta 0.94(3 \mathrm{H}, \mathrm{t}, J=7.5 \mathrm{~Hz}), 1.60$ $(2 \mathrm{H}, \mathrm{tq}, J=7.5,7.5 \mathrm{~Hz})$, and $2.16(2 \mathrm{H}, \mathrm{t}, J=7.5 \mathrm{~Hz})$. Therefore, the remaining three degrees of unsaturation identified compound $\mathbf{1}$ as a tricyclic molecule. Furthermore, the ${ }^{1} \mathrm{H}$ NMR data of $\mathbf{1}$ showed two secondary methyls $(\delta 0.78$ and $0.95,3 \mathrm{H}$ each, d, $J$ $=7.0 \mathrm{~Hz})$ of an isopropyl moiety. Inspection of the HMQC spectrum showed that proton signals appearing at $\delta 2.25(1 \mathrm{H}$, $\mathrm{dd}, J=12.0,7.1 \mathrm{~Hz}), 3.06(1 \mathrm{H}$, br t, $J=8.8 \mathrm{~Hz}), 3.57(1 \mathrm{H}, \mathrm{s})$, and $4.10(1 \mathrm{H}$, dd, $J=10.5,4.5 \mathrm{~Hz})$ were correlated to two ringjuncture methine carbons at $\delta 41.5$ and 46.1 and two oxymethine carbons at $\delta 90.5$ and 78.8, respectively. The gross structure of 1 was further established by 2D NMR experiments, especially by analysis of ${ }^{1} \mathrm{H}-{ }^{1} \mathrm{H}$ COSY and HMBC correlations (Figure 1). The ${ }^{1} \mathrm{H}-{ }^{1} \mathrm{H}$ COSY experiment assigned two isolated consecutive proton spin systems. One was found to extend from $\mathrm{H}_{2}-8$ to both $\mathrm{H}-12$ and the isopropyl moiety through $\mathrm{H}-14$. The other was shown to extend from $\mathrm{H}_{2}-4$ to $\mathrm{H}-6$. The HMBC correlations observed from $\mathrm{H}-2$ to $\mathrm{C}-1, \mathrm{C}-9, \mathrm{C}-10$, and $\mathrm{C}-14$ and $\mathrm{H}-9$ to $\mathrm{C}-7$ and $\mathrm{C}-11$ established the 2,9-ether linkage of the tetrahydrofuran moiety. On the basis of the above observations, compound 1 possessed the common C-2, C-9-ether linkage characteristic of eunicellin-based compounds. Furthermore, the position of the $n$-butyryloxy group attached at C-3 was confirmed from the NOE correlations (Figure 2) between $\mathrm{H}_{3}-20(\delta 0.78)$ and $\mathrm{H}-18(\delta$ 1.86) with the $\alpha$-methylene protons of the $n$-butyryloxy group $(\delta 2.16)$. From the above results, the structure of compound $\mathbf{1}$ was shown to be very similar to that of a known compound, palmonine $\mathrm{F}(\mathbf{1 0}) .^{7}$ The relative configuration of $\mathbf{1}$ was mostly confirmed to be the same as that of $\mathbf{1 0}$ by comparison 


\section{Chart 1}

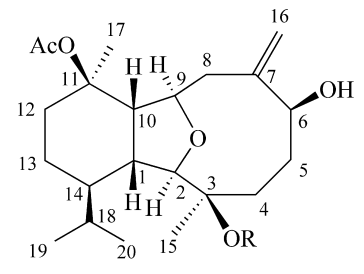

1: $\mathrm{R}=\mathrm{COCH}_{2} \mathrm{CH}_{2} \mathrm{CH}_{3}$ 10: $\mathrm{R}=\mathrm{Ac}$

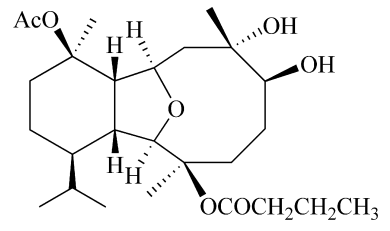

2

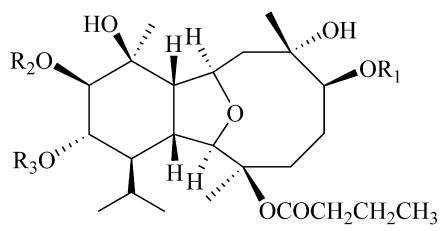

3: $\mathrm{R}_{1}=\mathrm{R}_{2}=\mathrm{Ac}, \mathrm{R}_{3}=\mathrm{COCH}_{2} \mathrm{CH}_{2} \mathrm{CH}_{3}$

4: $\mathrm{R}_{1}=\mathrm{COCH}_{2} \mathrm{CH}_{2} \mathrm{CH}_{3}, \mathrm{R}_{2}=\mathrm{Ac}, \mathrm{R}_{3}=\mathrm{COCH}_{2} \mathrm{CH}_{2} \mathrm{CH}_{3}$

5: $\mathrm{R}_{1}=\mathrm{COCH}=\mathrm{CH}_{2}, \mathrm{R}_{2}=\mathrm{Ac}, \mathrm{R}_{3}=\mathrm{COCH}_{2} \mathrm{CH}_{2} \mathrm{CH}_{3}$

6: $\mathrm{R}_{1}=\mathrm{R}_{2}=A c, \mathrm{R}_{3}=\mathrm{H}$

7: $\mathrm{R}_{1}=\mathrm{H}, \mathrm{R}_{2}=\mathrm{R}_{3}=\mathrm{Ac}$

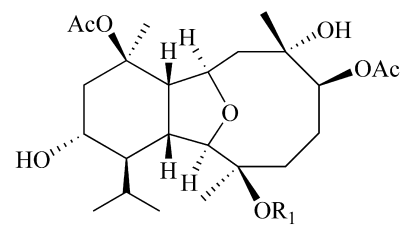

8: $\mathrm{R}_{1}=\mathrm{COCH}_{2} \mathrm{CH}_{2} \mathrm{CH}_{3}$ 9: $\mathrm{R}_{1}=\mathrm{Ac}$

Table 1. ${ }^{13} \mathrm{C}$ NMR Data for Compounds $\mathbf{1}-\mathbf{6}^{a}$

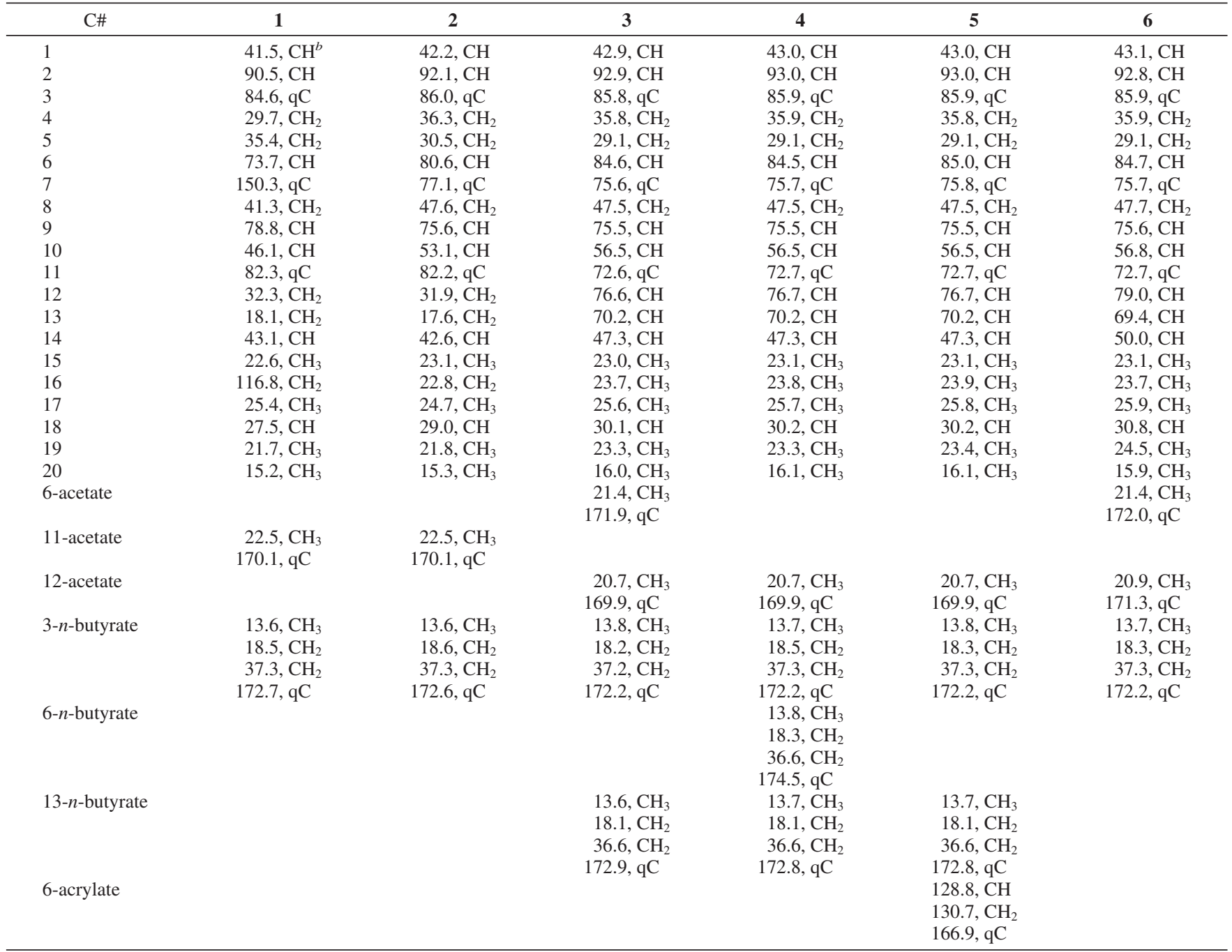

${ }^{a}$ Spectra recorded at $125 \mathrm{MHz}$ in $\mathrm{CDCl}_{3}$ at $25^{\circ} \mathrm{C} .{ }^{b}$ Attached protons were determined by DEPT experiments.

of the chemical shifts and coupling constants for protons of both compounds and was further confirmed by NOE correlations (Figure 2). The structure of $\mathbf{1}$ was thus found to possess the $\left(1 R^{*}, 2 R^{*}, 3 R^{*}, 6 S^{*}, 9 R^{*}, 10 S^{*}, 11 R^{*}, 14 R^{*}\right)$ configuration. The absolute structure of $\mathbf{1}$ was finally determined by using a modified Mosher's esterification methed. ${ }^{15}$ The $(S)$ - and $(R)$ MTPA esters of $\mathbf{1}$ (1a and $\mathbf{1} \mathbf{b}$, respectively) were prepared by using the corresponding $(R)-(-)$ - and $(S)-(+)$-MTPA chloride, 
Table 2. ${ }^{13} \mathrm{C}$ NMR Data for Compounds 7-9 ${ }^{a}$

\begin{tabular}{|c|c|c|c|}
\hline $\mathrm{C \#}$ & 7 & 8 & 9 \\
\hline 1 & $44.9, \mathrm{CH}^{b}$ & $44.2, \mathrm{CH}$ & $44.2, \mathrm{CH}$ \\
\hline 2 & $93.3, \mathrm{CH}$ & $93.2, \mathrm{CH}$ & $93.1, \mathrm{CH}$ \\
\hline 3 & $85.8, \mathrm{qC}$ & $85.9, \mathrm{qC}$ & $86.0, \mathrm{qC}$ \\
\hline 4 & $36.4, \mathrm{CH}_{2}$ & $36.0, \mathrm{CH}_{2}$ & $35.8, \mathrm{CH}_{2}$ \\
\hline 5 & $30.4, \mathrm{CH}_{2}$ & 29.1, $\mathrm{CH}_{2}$ & $29.1, \mathrm{CH}_{2}$ \\
\hline 6 & $80.5, \mathrm{CH}$ & $85.0, \mathrm{CH}$ & $84.9, \mathrm{CH}$ \\
\hline 7 & 77.0, qC & $75.8, \mathrm{qC}$ & 75.8, qC \\
\hline 8 & $47.5, \mathrm{CH}_{2}$ & 47.6, $\mathrm{CH}_{2}$ & 47.5, $\mathrm{CH}_{2}$ \\
\hline 9 & $75.7, \mathrm{CH}$ & $75.9, \mathrm{CH}$ & $76.0, \mathrm{CH}$ \\
\hline 10 & $56.8, \mathrm{CH}$ & $52.0, \mathrm{CH}$ & $51.3, \mathrm{CH}$ \\
\hline 11 & $72.6, \mathrm{qC}$ & $83.6, \mathrm{qC}$ & $83.6, \mathrm{qC}$ \\
\hline 12 & $76.7, \mathrm{CH}$ & $42.0, \mathrm{CH}_{2}$ & $42.3, \mathrm{CH}_{2}$ \\
\hline 13 & $70.5, \mathrm{CH}$ & $66.4, \mathrm{CH}$ & $66.4, \mathrm{CH}$ \\
\hline 14 & $47.4, \mathrm{CH}$ & $50.2, \mathrm{CH}$ & $50.1, \mathrm{CH}$ \\
\hline 15 & $23.3, \mathrm{CH}_{3}$ & $23.2, \mathrm{CH}_{3}$ & $23.1, \mathrm{CH}_{3}$ \\
\hline 16 & $22.7, \mathrm{CH}_{3}$ & $23.8, \mathrm{CH}_{3}$ & $23.8, \mathrm{CH}_{3}$ \\
\hline 17 & $25.7, \mathrm{CH}_{3}$ & $24.7, \mathrm{CH}_{3}$ & 24.6, $\mathrm{CH}_{3}$ \\
\hline 18 & $30.2, \mathrm{CH}$ & $30.4, \mathrm{CH}$ & $30.4, \mathrm{CH}$ \\
\hline 19 & $23.4, \mathrm{CH}_{3}$ & $23.8, \mathrm{CH}_{3}$ & $24.5, \mathrm{CH}_{3}$ \\
\hline 20 & $16.0, \mathrm{CH}_{3}$ & $16.1, \mathrm{CH}_{3}$ & $16.2, \mathrm{CH}_{3}$ \\
\hline \multirow[t]{2}{*}{3 -acetate } & & & $22.2, \mathrm{CH}_{3}$ \\
\hline & & & $169.8, \mathrm{qC}$ \\
\hline \multirow[t]{2}{*}{ 6-acetate } & & $21.4, \mathrm{CH}_{3}$ & $21.4, \mathrm{CH}_{3}$ \\
\hline & & $172.0, \mathrm{qC}$ & $172.0, \mathrm{qC}$ \\
\hline \multirow[t]{2}{*}{ 11-acetate } & & $22.4, \mathrm{CH}_{3}$ & $22.5, \mathrm{CH}_{3}$ \\
\hline & & $169.9, \mathrm{qC}$ & 170.1, qC \\
\hline \multirow[t]{2}{*}{ 12-acetate } & 20.6, $\mathrm{CH}_{3}$ & & \\
\hline & $170.0, \mathrm{qC}$ & & \\
\hline \multirow[t]{2}{*}{13 -acetate } & $21.4, \mathrm{CH}_{3}$ & & \\
\hline & 170.2, qC & & \\
\hline \multirow[t]{4}{*}{ 3-n-butyrate } & $13.7, \mathrm{CH}_{3}$ & 13.6, $\mathrm{CH}_{3}$ & \\
\hline & $18.3, \mathrm{CH}_{2}$ & 18.6, $\mathrm{CH}_{2}$ & \\
\hline & $37.2, \mathrm{CH}$ & 37.2, $\mathrm{CH}_{2}$ & \\
\hline & 172.1, qC & $172.5, \mathrm{qC}$ & \\
\hline
\end{tabular}

${ }^{a}$ Spectra recorded at $125 \mathrm{MHz}$ in $\mathrm{CDCl}_{3}$ at $25{ }^{\circ} \mathrm{C} .{ }^{b}$ Attached protons were determined by DEPT experiments.

respectively. The determination of $\Delta \delta$ values $\left(\delta_{S}-\delta_{R}\right)$ for protons neighboring C-6 led to the assignment of the $S$ configuration at C-6 in $\mathbf{1}$ (Figure 3 ).

The HRESIMS of simplexin B (2) exhibited a $[\mathrm{M}+\mathrm{Na}]^{+}$peak at $m / z 491.2987$ and established a molecular formula of $\mathrm{C}_{26} \mathrm{H}_{44} \mathrm{O}_{7}$, implying five degrees of unsaturation. The NMR spectroscopic data (Tables 1 and 3 ) of $\mathbf{2}$ showed the presence of two ester carbonyls $(\delta$ 170.1, qC and 172.6, qC), which were HMBC correlated with the acetate methyl $(\delta 1.99,3 \mathrm{H}, \mathrm{s})$ and methylenes $(\delta 1.68,2 \mathrm{H}$, tq, $J=7.5,7.5 \mathrm{~Hz}, 2.30, \mathrm{~m}$ and $2.35, \mathrm{~m}$ ) of an $n$-butyrate, respectively. By comparison of the NMR data of $\mathbf{2}$ with those of $\mathbf{1}$ (Tables 1 and 2), it was found that a C-7/C-16 double bond in $\mathbf{1}$ was replaced by an oxymethine bearing a methyl and a hydroxy group in $\mathbf{2}$, as confirmed by $\mathrm{HMBC}$ correlations observed from $\mathrm{H}_{3}-16(\delta 1.16$, $3 \mathrm{H}, \mathrm{s})$ to $\mathrm{C}-6(\delta 80.6, \mathrm{CH}), \mathrm{C}-7(\delta 77.1, \mathrm{qC})$, and $\mathrm{C}-8(\delta 47.6$, $\mathrm{CH}_{2}$ ). A more detailed analysis of the ${ }^{1} \mathrm{H}$ and ${ }^{13} \mathrm{C}$ NMR spectroscopic data and the detected $2 \mathrm{D}$ correlations in the ${ }^{1} \mathrm{H}-{ }^{1} \mathrm{H}$ COSY and $\mathrm{HMBC}$ spectra led to the establishment of the gross structure of 2 (Figure 1). The relative configurations of all chiral centers except C-7 of $\mathbf{2}$ were confirmed to be the same as those of $\mathbf{1}$ by comparison of the proton shifts, coupling constants, and NOE correlations (Figure 2). $\mathrm{H}_{3}-16$ was found to exhibit an NOE correlation with $\mathrm{H}-5 \beta$ but not with $\mathrm{H}-6$, revealing the $\alpha$-orientation of hydroxy group at C-7. Thus, the structure of diterpenoid 2 was established.

Simplexin C (3) showed the pseudomolecular ion peak [M + $\mathrm{Na}^{+}$at $\mathrm{m} / \mathrm{z}, 635.3409$ in the HRESIMS, corresponding to the molecular formula $\mathrm{C}_{32} \mathrm{H}_{52} \mathrm{O}_{11}$ and seven degrees of unsaturation. The ${ }^{13} \mathrm{C}$ NMR spectrum measured in $\mathrm{CDCl}_{3}$ showed signals of 32 carbons (Table 1), which were assigned by the assistance of the DEPT spectrum to nine methyls, seven methylenes, nine methines (including five oxymethines), four carbonyls, and three $\mathrm{sp}^{3}$ oxygenated quaternary carbons. The presence of two acetoxy groups was
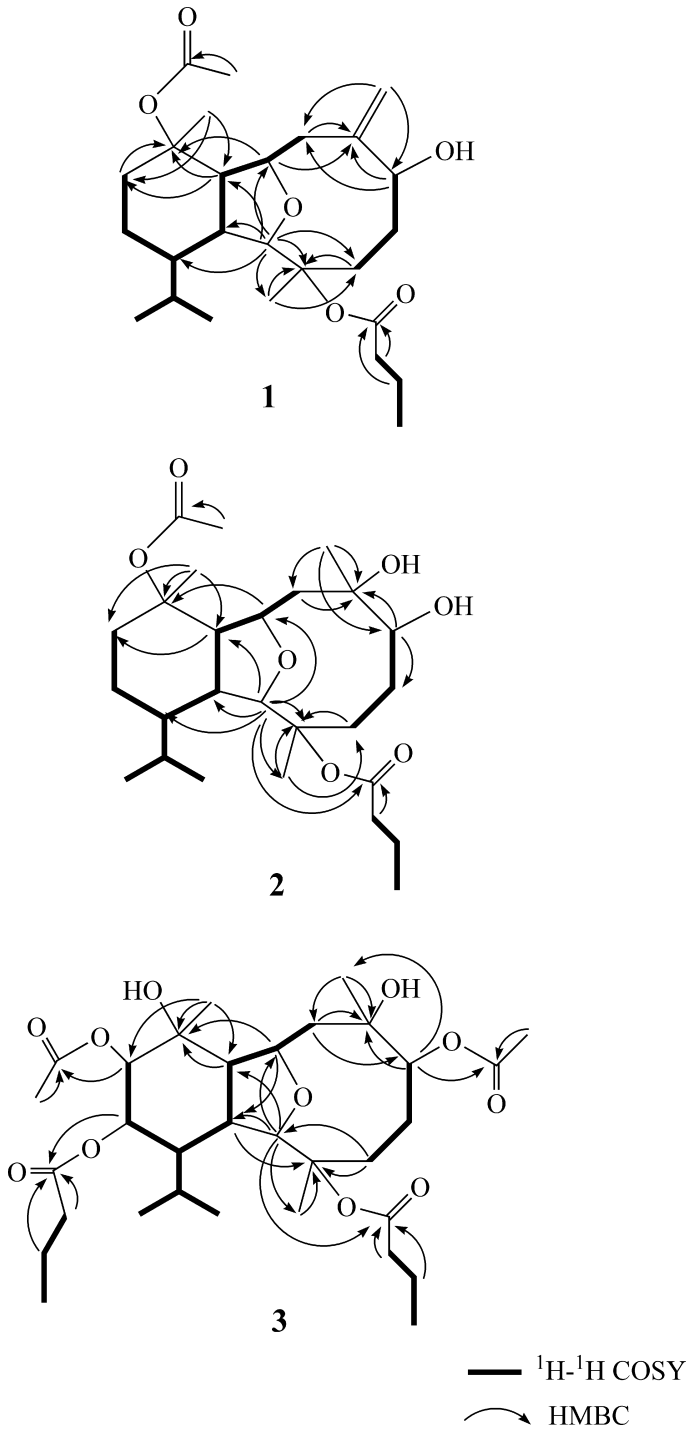

Figure 1. ${ }^{1} \mathrm{H}-{ }^{1} \mathrm{H}$ COSY and HMBC correlations for $\mathbf{1}-\mathbf{3}$.

indicated by the ${ }^{1} \mathrm{H}$ NMR signals at $\delta 2.05(\mathrm{~s}, 3 \mathrm{H})$ and $2.07(\mathrm{~s}$, $3 \mathrm{H})$ and the ${ }^{13} \mathrm{C}$ NMR signals at $\delta 20.7\left(\mathrm{CH}_{3}\right), 21.4\left(\mathrm{CH}_{3}\right), 169.9$ (qC), and 171.9 (qC). In addition, the ${ }^{1} \mathrm{H}$ and ${ }^{13} \mathrm{C}$ NMR spectra of 3 showed the presence of two $n$-butyryloxy groups. Among them one showed signals at $\delta_{\mathrm{H}} 0.97(3 \mathrm{H}, \mathrm{t}, J=7.5 \mathrm{~Hz}), 1.67(2 \mathrm{H}, \mathrm{m})$, $2.25(1 \mathrm{H}, \mathrm{m}), 2.37(1 \mathrm{H}, \mathrm{m})$ and $\delta_{\mathrm{C}} 13.8\left(\mathrm{CH}_{3}\right), 18.2\left(\mathrm{CH}_{2}\right), 37.2$ $\left(\mathrm{CH}_{2}\right), 172.2(\mathrm{qC})$, and the other resonated at $\delta_{\mathrm{H}} 0.92(3 \mathrm{H}, \mathrm{tq}, J=$ 7.5, 7.5 Hz), $1.60(2 \mathrm{H}$, sex, $J=7.5 \mathrm{~Hz}), 2.19(2 \mathrm{H}, \mathrm{dt}, J=2.0,7.5$ $\mathrm{Hz})$ and $\delta_{\mathrm{C}} 13.6\left(\mathrm{CH}_{3}\right), 18.1\left(\mathrm{CH}_{2}\right), 36.6\left(\mathrm{CH}_{2}\right), 172.9(\mathrm{qC})$. Therefore, the remaining three degrees of unsaturation identified compound $\mathbf{3}$ as a tricyclic diterpenoid. The molecular framework was established by ${ }^{1} \mathrm{H}-{ }^{1} \mathrm{H}$ COSY and $\mathrm{HMBC}$ experiments (Figure 1). The placement of acetates at C-6 and C- 12 was confirmed from the HMBC connectivities of acetate methyls ( $\delta 2.07$ and 2.05), H-6 $(\delta 5.58)$ and $\mathrm{H}-12(\delta 5.00)$ with the carbonyl carbons resonating at $\delta 171.9(\mathrm{qC})$ and $169.9(\mathrm{qC})$, respectively. Also, the locations of two $n$-butyryloxy groups at $\mathrm{C}-3$ and $\mathrm{C}$ - 13 were proven from the $\mathrm{HMBC}$ connectivities from $\mathrm{H}-2(\delta 3.53)$ and $\mathrm{H}-13(\delta 5.49)$ to the carbonyl carbons resonating at $\delta 172.2(\mathrm{qC})$ and $172.9(\mathrm{qC})$, respectively. The upfield chemical shifts for $\mathrm{H}_{3}-16(\delta 1.17)$ and $\mathrm{H}_{3}-17(\delta 1.10)$ determined the positions of two tertiary hydroxy groups at C-7 and C-11. Therefore, the gross structure of $\mathbf{3}$ was established. The relative configuration of compound $\mathbf{3}$ was determined from analysis of correlations observed in the NOESY spectrum (Figure 2), which exhibited NOE correlations between $\mathrm{H}-12$ and $\mathrm{H}-9$, and $\mathrm{H}-13$ and $\mathrm{H}-1$, and established the $\alpha$-orientation 
Table 3. ${ }^{1} \mathrm{H}$ NMR Data for Compounds $\mathbf{1}-\mathbf{5}^{a}$

\begin{tabular}{|c|c|c|c|c|c|}
\hline $\mathrm{H \#}$ & 1 & 2 & 3 & 4 & 5 \\
\hline 1 & $2.25, \mathrm{dd}(12.0,7.1)^{b}$ & $2.17, \mathrm{dd}(11.2,7.5)$ & $2.38, \mathrm{~m}$ & $2.41, \mathrm{dd}(11.5,7.5)$ & $2.42, \mathrm{dd}(11.0,7.5)$ \\
\hline 2 & $3.57, \mathrm{~s}$ & $3.49, \mathrm{~s}$ & $3.53, \mathrm{~s}$ & $3.55, \mathrm{~s}$ & $3.56, \mathrm{~s}$ \\
\hline $4 \alpha$ & $2.14, \mathrm{~d}(8.5)$ & $1.79, \mathrm{~d}(14.5)$ & $1.99, \mathrm{dd}(13.5,11.0)$ & $2.02, \mathrm{dd}(14.5,10.0)$ & $2.05, \mathrm{~m}$ \\
\hline $5 \alpha$ & $2.10, \mathrm{~m}$ & $1.57, \mathrm{~m}$ & $1.50, \mathrm{dd}(16.5,8.5)$ & $1.52, \mathrm{dd}(16.7,8.5)$ & $1.57, \mathrm{~m}$ \\
\hline $5 \beta$ & $1.74, \mathrm{~m}$ & $1.46, \mathrm{~m}$ & $1.40, \mathrm{~m}$ & $1.41, \mathrm{~m}$ & $1.47, \mathrm{dd}(10.5,5.5)$ \\
\hline 6 & $4.30, \mathrm{dd}(12.5,3.0)$ & $4.57, \mathrm{~d}(6.0)$ & $5.58, \mathrm{~d}(6.0)$ & $5.60, \mathrm{~d}(5.5)$ & $5.69, \mathrm{~d}(5.5)$ \\
\hline 9 & $4.10, \mathrm{dd}(10.5,4.5)$ & 4.06, ddd $(11.0,7.5,3.5)$ & 4.27, ddd $(11.0,7.5,3.5)$ & 4.29, ddd $(11.5,7.5,3.5)$ & $4.31, \mathrm{ddd}(11.0,7.5,3.5)$ \\
\hline 10 & 3.06, br t $(8.8)$ & $3.08, \mathrm{t}(7.5)$ & $2.60, \mathrm{t}(7.5)$ & $2.63, \mathrm{t}(7.5)$ & $2.64, \mathrm{t}(7.5)$ \\
\hline 12 & $\begin{array}{l}\alpha: 1.44, \mathrm{~m} \\
\beta: 2.27, \mathrm{~d}(12.0)\end{array}$ & $\begin{array}{l}\alpha: 1.44, \mathrm{~m} \\
\beta: 2.21, \mathrm{~d}(14.0)\end{array}$ & $5.00, \mathrm{~d}(10.0)$ & $5.03, \mathrm{~d}(9.5)$ & $5.03, \mathrm{~d}(9.5)$ \\
\hline 13 & $\begin{array}{l}\alpha: 1.46, \mathrm{~m} \\
\beta: 1.35, \mathrm{t}(12.0)\end{array}$ & $\begin{array}{l}\alpha: 1.42, \mathrm{~m} \\
\beta: 1.33, \mathrm{~m}\end{array}$ & $5.49, \mathrm{t}(10.0)$ & $5.50, \mathrm{dd}(11.5,9.5)$ & $5.50, \mathrm{dd}(11.0,9.5)$ \\
\hline 14 & 1.20 , br t (12.0) & $1.14, \mathrm{~m}$ & $1.73, \mathrm{t}(11.5)$ & $1.75, \mathrm{~m}$ & $1.76, \mathrm{t}(11.0)$ \\
\hline 20 & $0.78,3 \mathrm{H}, \mathrm{d}(7.0)$ & $0.82, \mathrm{~d}(7.0)$ & $0.94,3 \mathrm{H}, \mathrm{d}(7.0)$ & $0.96,3 \mathrm{H}, \mathrm{d}(7.0)$ & $0.96,3 \mathrm{H}, \mathrm{d}(7.0)$ \\
\hline 6-acetate & & & $2.07,3 \mathrm{H}, \mathrm{s}$ & & \\
\hline 11-acetate & $2.01,3 \mathrm{H}, \mathrm{s}$ & $1.99,3 \mathrm{H}, \mathrm{s}$ & & & \\
\hline 12-acetate & & & $2.05,3 \mathrm{H}, \mathrm{s}$ & $2.07,3 \mathrm{H}, \mathrm{s}$ & $2.07,3 \mathrm{H}, \mathrm{s}$ \\
\hline \multirow[t]{4}{*}{ 3-n-butyrate } & $0.94,3 \mathrm{H}, \mathrm{t}(7.5)$ & $1.00,3 \mathrm{H}, \mathrm{t}(7.5)$ & $0.97,3 \mathrm{H}, \mathrm{t}(7.5)$ & $0.97,3 \mathrm{H}, \mathrm{t}(7.5)$ & $0.99,3 \mathrm{H}, \mathrm{t}(7.5)$ \\
\hline & $1.60,2 \mathrm{H}, \mathrm{tq}(7.5,7.5)$ & $1.68,2 \mathrm{H}, \mathrm{tq}(7.5,7.5)$ & $1.67,2 \mathrm{H}, \mathrm{m}$ & $1.68,2 \mathrm{H}, \mathrm{m}$ & $1.68,2 \mathrm{H}, \mathrm{m}$ \\
\hline & $2.16,2 \mathrm{H}, \mathrm{t}(7.5)$ & $2.30, \mathrm{~m}$ & $2.25, \mathrm{~m}$ & $2.27, \mathrm{~m}$ & $2.28, \mathrm{~m}$ \\
\hline & & $2.35, \mathrm{~m}$ & $2.37, \mathrm{~m}$ & $2.39, \mathrm{~m}$ & $2.40, \mathrm{~m}$ \\
\hline \multirow[t]{3}{*}{ 6-n-butyrate } & & & & $0.94,3 \mathrm{H}, \mathrm{t}(7.5)$ & \\
\hline & & & & $1.66,2 \mathrm{H}, \mathrm{m}$ & \\
\hline & & & & $2.32,2 \mathrm{H}, \mathrm{t}(7.5)$ & \\
\hline \multirow[t]{2}{*}{ 13-n-butyrate } & & & $0.92,3 \mathrm{H}, \mathrm{t}(7.5)$ & $0.96,3 \mathrm{H}, \mathrm{t}(7.5)$ & $0.95,3 \mathrm{H}, \mathrm{t}(7.5)$ \\
\hline & & & $1.60,2 \mathrm{H}, \mathrm{tq}(7.5,7.5)$ & $1.61,2 \mathrm{H}, \mathrm{tq}(7.5,7.5)$ & $1.60,2 \mathrm{H}, \mathrm{tq}(7.5,7.5)$ \\
\hline
\end{tabular}

${ }^{a}$ Spectra recorded at $500 \mathrm{MHz}$ in $\mathrm{CDCl}_{3}$ at $25{ }^{\circ} \mathrm{C} .{ }^{b}$ The $J$ values are in $\mathrm{Hz}$ in parentheses.

of $\mathrm{H}-12$ and the $\beta$-orientation of H-13. By comparison of the NMR spectroscopic data of $\mathbf{2}$ and $\mathbf{3}$ and by detailed analysis of other key NOE correlations (Figure 2), the structure of compound $\mathbf{3}$ was determined unambiguously.

Simplexin D (4) was found to have the molecular formula $\mathrm{C}_{34} \mathrm{H}_{56} \mathrm{O}_{11}$, as indicated from the HRESIMS $(\mathrm{m} / \mathrm{z}, 663.3718[\mathrm{M}+$ $\mathrm{Na}^{+}$) and NMR data (Tables 1 and 3). Comparison of the NMR data of $\mathbf{4}$ with those of $\mathbf{3}$ revealed the replacement of one acetoxy group $\left(\delta_{\mathrm{H}} 2.07,3 \mathrm{H}, \mathrm{s} ; \delta_{\mathrm{C}} 171.9, \mathrm{qC}\right.$ and $\left.21.4, \mathrm{CH}_{3}\right)$ in 3 by an $n$-butyryloxy group in $4\left(\delta_{\mathrm{H}} 0.94,3 \mathrm{H}, \mathrm{t}, J=7.5 \mathrm{~Hz} ; 1.66,2 \mathrm{H}, \mathrm{m}\right.$; $2.32,2 \mathrm{H}, \mathrm{t}, J=7.5 \mathrm{~Hz} ; \delta_{\mathrm{C}} 174.5, \mathrm{qC} ; 36.6, \mathrm{CH}_{2} ; \delta_{\mathrm{C}} 18.3, \mathrm{CH}_{2}$ and $13.8, \mathrm{CH}_{3}$ ). It was further confirmed by the $\mathrm{HMBC}$ experiment, which showed a correlation between H-6 and the carbonyl carbon $\left(\delta_{\mathrm{C}} 174.5, \mathrm{qC}\right)$ of an $n$-butyryloxy group. The correlations observed in the NOESY spectrum of $\mathbf{4}$ also showed that the configuration of this metabolite is identical with that of $\mathbf{3}$. Thus, simplexin D (4) was found to be the 6-O-deacetyl-6- $O$ - $n$-butyryl derivative of $\mathbf{3}$.

Simplexin E (5) was obtained as a colorless oil. On the basis of its HRESIMS $\left(\mathrm{m} / \mathrm{z}, 647.3410[\mathrm{M}+\mathrm{Na}]^{+}\right)$, along with the ${ }^{1} \mathrm{H}$ and ${ }^{13} \mathrm{C}$ NMR spectroscopic data (Tables 1 and 3 ), the molecular formula of $\mathbf{5}$ was established as $\mathrm{C}_{33} \mathrm{H}_{52} \mathrm{O}_{11}$, consistent with eight degrees of unsaturation. The IR spectrum of $\mathbf{5}$ showed the presence of hydroxy $\left(v_{\max } 3478 \mathrm{~cm}^{-1}\right)$, carbonyl $\left(v_{\max } 1733 \mathrm{~cm}^{-1}\right)$, and double-bond $\left(v_{\max } 1636 \mathrm{~cm}^{-1}\right)$ functionalities. Comparison of its ${ }^{1} \mathrm{H}$ NMR (Table 1) and ${ }^{13} \mathrm{C}$ NMR (Table 3) data with those of $\mathbf{3}$ revealed that an acetate in $\mathbf{3}$ was replaced by an acrylate $\left(\delta_{\mathrm{H}} 5.84\right.$, $\mathrm{dd}, J=10.5,1.5 \mathrm{~Hz} ; 6.15$, dd, $J=17.5,10.5 \mathrm{~Hz} ; 6.40$, dd, $J=$ 17.5, $1.5 \mathrm{~Hz} ; \delta_{\mathrm{C}} 166.9, \mathrm{qC} ; 128.8, \mathrm{CH}$ and $\left.130.7 \mathrm{CH}_{2}\right)$ in $\mathbf{5}$. The attachment of this acrylate at C-6 was confirmed by the HMBC correlation between H- 6 and the carbonyl carbon $\left(\delta_{\mathrm{C}} 166.9, \mathrm{qC}\right)$ of the acrylate. H-6 exhibited an NOE interaction with $\mathrm{H}-4 \alpha$, revealing the $\beta$-orientation of the acrylate. A detailed analysis of other key NOE correlations further showed that $\mathbf{5}$ has the same relative configuration as those of $\mathbf{3}$ and $\mathbf{4}$. A structurally similar metabolite, simplexin F (6), was also isolated as a white powder. Its molecular formula, $\mathrm{C}_{28} \mathrm{H}_{46} \mathrm{O}_{10}$, was established by HRESIMS $\left(m / z\right.$ 565.2987, $\left.[\mathrm{M}+\mathrm{Na}]^{+}\right)$. The ${ }^{1} \mathrm{H}$ and ${ }^{13} \mathrm{C} \mathrm{NMR}$ data (Tables 1 and 4 ) revealed that 6 is simply the 13-Odebutyryl derivative of $\mathbf{3}$.

Simplexin G (7) was obtained as a white powder. Its molecular formula, $\mathrm{C}_{28} \mathrm{H}_{46} \mathrm{O}_{10}$, was determined by HRESIMS ( $\mathrm{m} / \mathrm{z} 565.2991$ $[\mathrm{M}+\mathrm{Na}]^{+}$). The NMR spectra of 7 (Tables 2 and 4) showed the presence of two acetoxy and one $n$-butyryloxy group. The HMBC correlations of $\mathrm{H}-12(\delta 5.01)$ and $\mathrm{H}-13(\delta 5.47)$ with the carbonyl carbons resonating at $\delta 170.0(\mathrm{qC})$ and $170.2(\mathrm{qC})$, respectively, revealed the location of two acetoxy groups at $\mathrm{C}-12$ and $\mathrm{C}-13$. Thus, 7 is the 6-O-deacetyl-13- $O$-acetyl derivative of $\mathbf{6}$.

Simplexin $\mathrm{H}(\mathbf{8})$ was isolated as a white powder and has a molecular formula of $\mathrm{C}_{28} \mathrm{H}_{46} \mathrm{O}_{9}$, appropriate for six degree of unsaturation. Comparison of the NMR data of $\mathbf{8}$ with those of $\mathbf{2}$ showed that the methylene group of C-13 in $\mathbf{2}$ was converted to an oxymethine carbon bearing a hydroxy group $\left(\delta_{\mathrm{H}} 3.88,1 \mathrm{H} \mathrm{m} ; \delta_{\mathrm{C}}\right.$ $66.4, \mathrm{CH})$ in $\mathbf{8}$. Also, $\mathrm{H}-6$ and $\mathrm{C}-6$ of $\mathbf{8}$ were downfield shifted to $\delta 5.60$ and 85.0, respectively, in comparison with those of 2 . Thus, an acetoxy group was attached at C- 6 . This was further confirmed by the HMBC correlations from H-6 and the methyl protons of an acetate $\left(\delta_{\mathrm{H}} 2.08,3 \mathrm{H}, \mathrm{s}\right)$ to a carbonyl carbon $(\delta 172.0$, qC). Thus, the planar structure of $\mathbf{8}$ was fully established. The relative configuration of $\mathbf{8}$ was also deduced using a NOESY spectrum and was found to be similar to that of $\mathbf{2}$. In addition, $\mathrm{H}-13$ shows NOE 

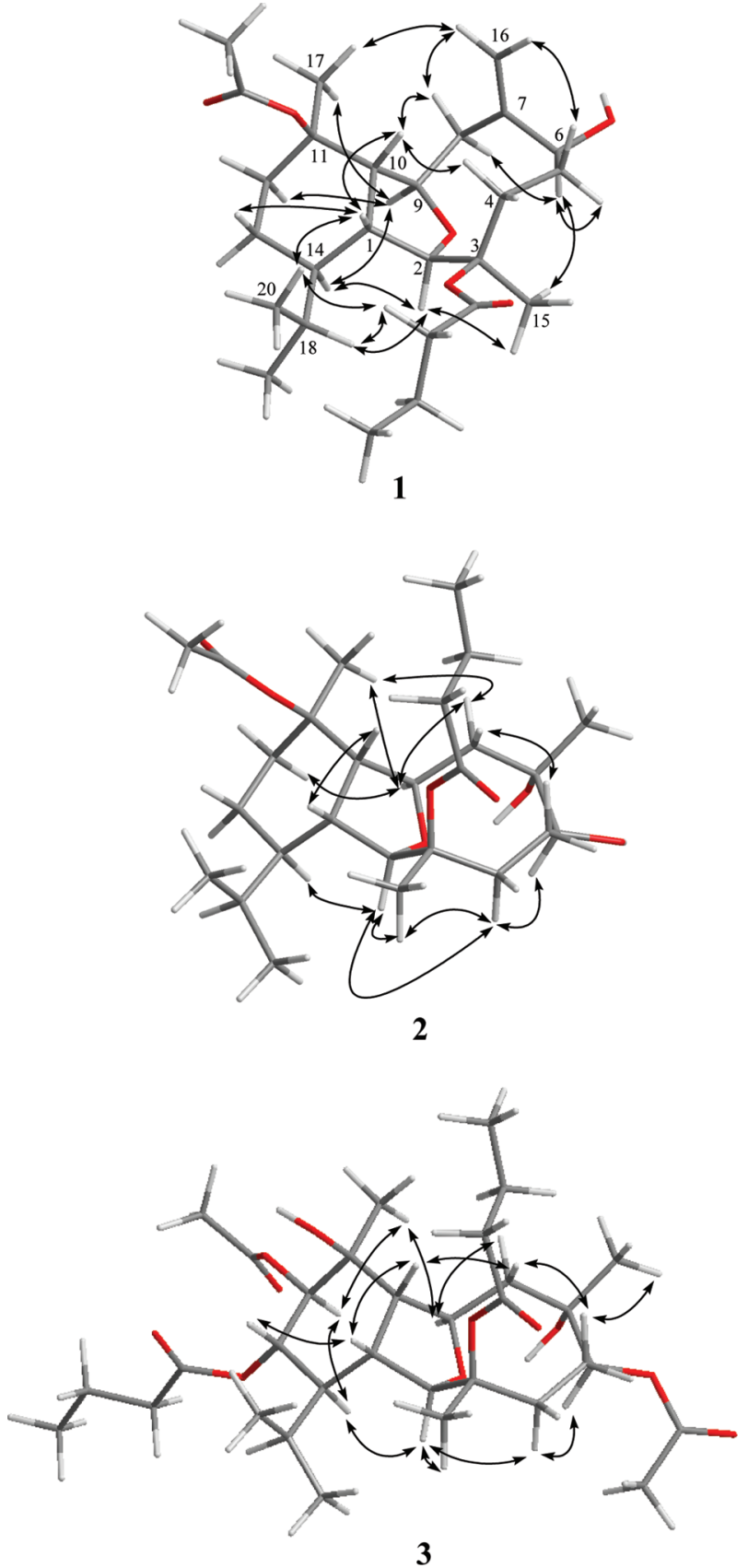

Figure 2. Selective NOE correlations for $\mathbf{1} \mathbf{- 3}$.

response with $\mathrm{H}-1$ and $\mathrm{H}-12 \beta$, but not with $\mathrm{H}-14$ (Figure 2), revealing the $\beta$-orientation of $\mathrm{H}-13$. Therefore, the structure of $\mathbf{8}$ was found to possess the $\left(1 R^{*}, 2 R^{*}, 3 R^{*}, 6 S^{*}, 7 S^{*}, 9 R^{*}, 10 S^{*}\right.$, $\left.11 R^{*}, 13 R^{*}, 14 R^{*}\right)$ configuration.

Simplexin I (9) was assigned the molecular formula $\mathrm{C}_{26} \mathrm{H}_{42} \mathrm{O}_{9}$ from its HRESIMS data. Thus, six degrees of unsaturation were determined for $\mathbf{9}$. NMR spectroscopic data of 9 (Tables 2 and 4) showed the presence of three acetoxy groups $\left(\delta_{\mathrm{C}} 169.8, \mathrm{qC} ; 170.1\right.$, $\mathrm{qC} ; 172.0, \mathrm{qC} ; 21.4, \mathrm{CH}_{3} ; 22.2, \mathrm{CH}_{3}$ and $22.5, \mathrm{CH}_{3} ; \delta_{\mathrm{H}} 2.00,3 \mathrm{H}$, s; $2.09,3 \mathrm{H}, \mathrm{s}$ and $2.10,3 \mathrm{H}, \mathrm{s})$. Comparison of the NMR data of 9 with those of $\mathbf{8}$ revealed the only difference between both compounds arises from the replacement of the $n$-butyryloxy moiety at $\mathrm{C}-3$ in $\mathbf{8}$ by an acetoxy group in $\mathbf{9}$.

The cytotoxicity of compounds $\mathbf{1}-\mathbf{6}$ and $\mathbf{9}$ against the proliferation of a limited panel of cancer cell lines, including human medulloblastoma (Daoy), human breast adenocarcinoma (MCF-7), human cervical epitheloid carcinoma (HeLa), and human laryngeal carcinoma (Hep2) was studied. The results (Table 5) showed that

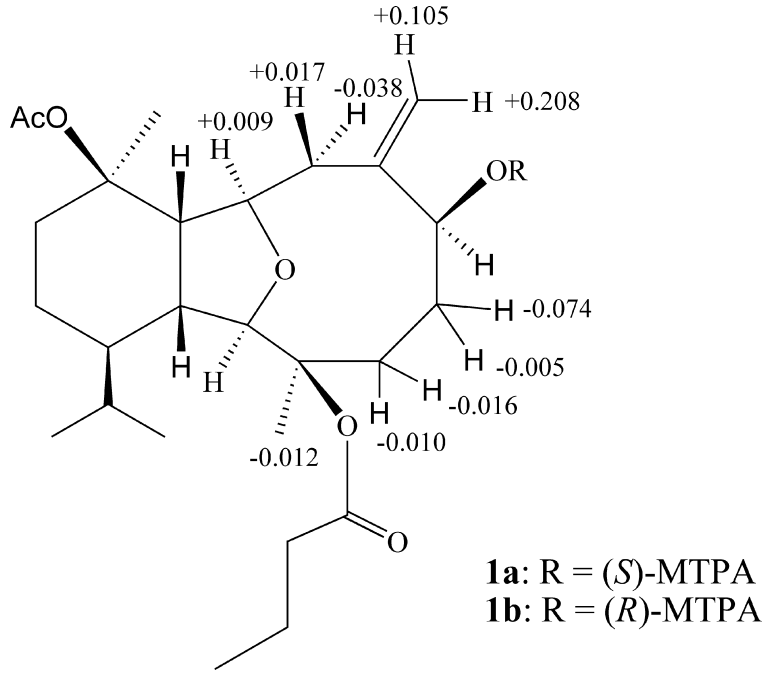

Figure 3. H NMR chemical shift differences $\Delta \delta\left(\delta_{S}-\delta_{R}\right)$ in ppm for the MTPA esters of $\mathbf{1}$.

compounds $2,3,6$, and 9 are not cytotoxic toward the above cancer cells. Compound $\mathbf{5}$ exhibited moderate to weak cytotoxicity toward the above four cancer cell lines, and compounds $\mathbf{1}$ and $\mathbf{4}$ displayed weak cytotoxicity toward Daoy and MCF-7 cancer cell lines.

The in vitro anti-inflammatory effects of compounds $\mathbf{1 - 6}$ and 9 were tested. In this assay, the up-regulation of the pro-inflammatory iNOS and COX-2 proteins of LPS-stimulated RAW264.7 macrophage cells was evaluated using immunoblot analysis. At a concentration of $10 \mu \mathrm{M}$, compound $\mathbf{5}$ was found to significantly reduce the levels of iNOS and COX-2 proteins to $4.8 \pm 1.8 \%$ and $37.7 \pm 4.7 \%$, respectively, relative to the control cells stimulated with LPS only. At the same concentration, metabolites $\mathbf{1}$ and $\mathbf{4}$ did not inhibit the COX-2 expression, but could significantly reduce iNOS expression $(15.9 \pm 14.5 \%$ and $37.7 \pm 7.2 \%$, respectively) by LPS treatment (Figure 4 ).

\section{Experimental Section}

General Experimental Procedures. Melting points were determined using a Fisher-Johns melting point apparatus and were uncorrected. Optical rotations were measured on a JASCO DIP-1000 digital polarimeter. The UV spectrum of $\mathbf{5}$ was taken in $\mathrm{MeOH}$ on a Hitachi U-3210 UV spectrometer. IR spectra were recorded on a JASCO FT/ IR-4100 infrared spectrophotometer. ESIMS were obtained with a Bruker APEX II mass spectrometer. The NMR spectra were recorded on a Varian Unity INOVA 500 FT-NMR at $500 \mathrm{MHz}$ for ${ }^{1} \mathrm{H}$ and 125 $\mathrm{MHz}$ for ${ }^{13} \mathrm{C}$ or on a Varian $400 \mathrm{MR}$ FT-NMR at $400 \mathrm{MHz}$ for ${ }^{1} \mathrm{H}$ and $100 \mathrm{MHz}$ for ${ }^{13} \mathrm{C}$, respectively, in $\mathrm{CDCl}_{3}$ using TMS as an internal standard. Si gel 60 (Merck, 230-400 mesh) was used for column chromatography. Precoated silica gel plates (Merck, Kieselgel $60 \mathrm{~F}_{254}$, $0.2 \mathrm{~mm}$ ) were used for analytical TLC. High-performance liquid chromatography was performed on a Hitachi L-7100 HPLC apparatus with a Merck Hibar Si-60 column $(250 \times 21 \mathrm{~mm}, 7 \mu \mathrm{m})$.

Animal Materials. Klyxum simplex (230 g, wet wt) was collected by hand using scuba off the coast of Dongsha Atoll, in September 2006, at a depth of $10.9 \mathrm{~m}$, and stored in a freezer until extraction. A voucher sample (specimen no. 20060901-1) was deposited at the Department of Marine Biotechnology and Resources, Sun Yat-sen University.

Extraction and Isolation. The frozen bodies of $K$. simplex $(230 \mathrm{~g}$, wet wt) were minced and exhaustively extracted with EtOAc $(1 \mathrm{~L} \times$ 4 ). The organic extract was evaporated under reduced pressure to give a residue $(2.5 \mathrm{~g})$, which was subjected to $\mathrm{Si}$ gel column chromatography and eluted with EtOAc in $n$-hexane $(0-100 \%$, gradient) to yield 22 fractions. Fractions $10-12(1.05 \mathrm{~g})$, eluted with EtOAc- $n$-hexane (1:3), were further purified over silica gel using EtOAc- $n$-hexane (1:3 to $1: 1)$ to afford 46 subfractions. Subfraction 13 was separated by normal-phase HPLC using acetone- $n$-hexane (1:6) to afford 7 (1.6 $\mathrm{mg}$ ), subfraction 27 was purified by normal-phase HPLC using acetone $-n$-hexane (1:5) to afford $\mathbf{1}(4.6 \mathrm{mg})$, subfraction 34 was also 
Table 4. ${ }^{1} \mathrm{H}$ NMR Data for Compounds $6-9^{a}$

\begin{tabular}{|c|c|c|c|c|}
\hline $\mathrm{H \#}$ & 6 & 7 & 8 & 9 \\
\hline 1 & $2.33, \mathrm{dd}(11.5,7.0)^{b}$ & $2.38, \mathrm{~m}$ & $2.13, \mathrm{dd}(10.8,7.0)$ & $2.11, \mathrm{~m}$ \\
\hline 2 & $3.54, \mathrm{~s}$ & $3.55, \mathrm{~s}$ & $3.55, \mathrm{~s}$ & $3.54, \mathrm{~s}$ \\
\hline $4 \alpha$ & $2.00, \mathrm{dd}(15.0,10.0)$ & $1.82, \mathrm{~m}$ & $1.99, \mathrm{~m}$ & $1.99, \mathrm{~m}$ \\
\hline $5 \alpha$ & $1.52, \mathrm{dd}(16.5,8.5)$ & $1.59, \mathrm{~m}$ & $1.54, \mathrm{~m}$ & $1.51, \mathrm{~m}$ \\
\hline $5 \beta$ & $1.43, \mathrm{~m}$ & $1.42, \mathrm{~m}$ & $1.45, \mathrm{~m}$ & $1.44, \mathrm{~m}$ \\
\hline 6 & $5.60, \mathrm{~d}(6.0)$ & $4.56, \mathrm{~d}(6.0)$ & $5.60, \mathrm{~d}(5.5)$ & $5.60, \mathrm{~d}(5.5)$ \\
\hline 9 & 4.26, ddd $(11.0,7.5,4.0)$ & $4.24, \mathrm{~m}$ & 4.12, ddd $(11.0,7.5,3.5)$ & $4.11, \operatorname{ddd}(11.0,8.0,3.5)$ \\
\hline 10 & $2.59, \mathrm{t}(7.5)$ & $2.60, \mathrm{t}(7.0)$ & $3.17, \mathrm{t}(7.5)$ & $3.26, \mathrm{t}(7.5)$ \\
\hline 12 & $4.87, \mathrm{~d}(9.5)$ & $5.01, \mathrm{~d}(10.0)$ & $\begin{array}{l}\alpha: 1.48, \mathrm{~m} \\
\beta: 2.32, \mathrm{~m}\end{array}$ & $\begin{array}{l}\alpha: 1.46, \mathrm{~m} \\
\beta: 2.26, \mathrm{dd}(13.0,2.5)\end{array}$ \\
\hline 13 & $2.99, \mathrm{dd}(11.5,9.5)$ & $5.47, \mathrm{t}(10.0)$ & $3.88, \mathrm{~m}$ & $3.90, \operatorname{td}(11.0,3.5)$ \\
\hline 14 & $1.44, \mathrm{t}(11.5)$ & $1.71, \mathrm{~m}$ & $1.22, \mathrm{~m}$ & $1.19, \mathrm{~m}$ \\
\hline 15 & $1.40,3 \mathrm{H}, \mathrm{s}$ & $1.40,3 \mathrm{H}, \mathrm{s}$ & $1.39,3 \mathrm{H}, \mathrm{s}$ & $1.41,3 \mathrm{H}, \mathrm{s}$ \\
\hline 3 -acetate & & & & $2.10,3 \mathrm{H}, \mathrm{s}$ \\
\hline 6 -acetate & $2.08,3 \mathrm{H}, \mathrm{s}$ & & $2.08,3 \mathrm{H}, \mathrm{s}$ & $2.09,3 \mathrm{H}, \mathrm{s}$ \\
\hline 11-acetate & & & $1.98,3 \mathrm{H}, \mathrm{s}$ & $2.00,3 \mathrm{H}, \mathrm{s}$ \\
\hline 12-acetate & $2.18,3 \mathrm{H}, \mathrm{s}$ & $2.18,3 \mathrm{H}, \mathrm{s}$ & & \\
\hline 13-acetate & & $2.08,3 \mathrm{H}, \mathrm{s}$ & & \\
\hline \multirow[t]{4}{*}{ 3-n-butyrate } & $0.99,3 \mathrm{H}, \mathrm{t}(7.5)$ & $0.98,3 \mathrm{H}, \mathrm{t}(7.0)$ & $0.99,3 \mathrm{H}, \mathrm{t}(7.5)$ & \\
\hline & $1.69,2 \mathrm{H}, \mathrm{m}$ & $1.67,2 \mathrm{H}, \mathrm{m}$ & $1.67,2 \mathrm{H}, \mathrm{m}$ & \\
\hline & $2.28, \mathrm{~m}$ & $2.27, \mathrm{~m}$ & $2.30, \mathrm{~m}$ & \\
\hline & $2.37, \mathrm{~m}$ & $2.39, \mathrm{~m}$ & $2.34, \mathrm{~m}$ & \\
\hline
\end{tabular}

${ }^{a}$ Spectra recorded at $500 \mathrm{MHz}$ in $\mathrm{CDCl}_{3}$ at $25{ }^{\circ} \mathrm{C} .{ }^{b} J$ values are (in $\mathrm{Hz}$ ) in parentheses.

Table 5. Cytotoxicity $\left(\mathrm{ED}_{50} \mu \mathrm{g} / \mathrm{mL}\right)$ of Compounds $\mathbf{1 - 6}$ and 9

\begin{tabular}{lllll}
\hline compound & Daoy & MCF-7 & HeLa & Hep2 \\
\hline $\mathbf{1}$ & 10.37 & 12.06 & $(-)^{a}$ & 12.10 \\
$\mathbf{2}$ & $(-)$ & $(-)$ & $(-)$ & $(-)$ \\
$\mathbf{3}$ & $(-)$ & $(-)$ & $(-)$ & $(-)$ \\
$\mathbf{4}$ & 15.34 & 14.54 & $(-)$ & $(-)$ \\
$\mathbf{5}$ & 12.76 & 7.19 & 17.36 & 10.72 \\
$\mathbf{6}$ & $(-)$ & $(-)$ & $(-)$ & $(-)$ \\
$\mathbf{9}$ & $(-)$ & $(-)$ & $(-)$ & $(-)$ \\
mitomycin & 0.09 & 0.14 & 0.08 & 0.02 \\
\hline
\end{tabular}

${ }^{a}(-): \mathrm{ED}_{50}>20 \mu \mathrm{g} / \mathrm{mL}$.

purified by normal-phase HPLC using acetone $-n$-hexane (1:3) to afford $4(10.1 \mathrm{mg})$, and subfraction 37 was also separated by normal-phase HPLC using acetone $-n$-hexane (1:2) to give $\mathbf{5}(10.4 \mathrm{mg}), \mathbf{8}(2.8 \mathrm{mg})$, and $9(8.0 \mathrm{mg})$. Fractions $13-15$ (0.47 g), eluted with EtOAc- $n$-hexane (1:1), were further purified over silica gel using EtOAc- $n$-hexane (1:1) to afford 19 subfractions. Subfractions 17 and 19 were separated by normal-phase HPLC using acetone $-n$-hexane (1:2) to yield 2 (8.0 $\mathrm{mg})$ and $6(9.6 \mathrm{mg})$, respectively. Fractions 16-19 (0.51 g), eluted with EtOAc- $n$-hexane (2:1), were further purified over silica gel using EtOAc $-n$-hexane (2:1) to afford four subfractions. Subfraction 2 was separated by normal-phase HPLC using $\mathrm{MeOH}-\mathrm{CH}_{2} \mathrm{Cl}_{2}$ (1:30) to afford 3 (37.2 mg).

Simplexin A (1): colorless oil (4.6 mg); $[\alpha]_{\mathrm{D}}^{26}-8.9\left(c 0.8, \mathrm{CHCl}_{3}\right)$; IR (neat) $v_{\max } 3432$ (broad) and $1723 \mathrm{~cm}^{-1} ;{ }^{1} \mathrm{H}$ and ${ }^{13} \mathrm{C}$ NMR data, see Tables 1 and 3; ESIMS m/z 473 [100, $(\mathrm{M}+\mathrm{Na})^{+}$]; HRESIMS $\mathrm{m} / \mathrm{z}$ 473.2879 (calcd for $\mathrm{C}_{26} \mathrm{H}_{42} \mathrm{O}_{6} \mathrm{Na}, 473.2877$ ).

Simplexin B (2): colorless oil $(8.0 \mathrm{mg}) ;[\alpha]_{\mathrm{D}}^{26}+26\left(c 0.7, \mathrm{CHCl}_{3}\right)$; IR (neat) $v_{\max } 3442$ (broad) and $1731 \mathrm{~cm}^{-1} ;{ }^{1} \mathrm{H}$ and ${ }^{13} \mathrm{C}$ NMR data, see Tables 1 and 3; ESIMS $m / z 491$ [100, $(\mathrm{M}+\mathrm{Na})^{+}$], $451(16)$; HRESIMS $\mathrm{m} / z 491.2987$ (calcd for $\mathrm{C}_{26} \mathrm{H}_{44} \mathrm{O}_{7} \mathrm{Na}, 491.2985$ ).

Simplexin C (3): white powder (37.2 mg); mp 93.0-94.0 ${ }^{\circ} \mathrm{C} ;[\alpha]_{\mathrm{D}}^{26}$ +29.7 (c 0.64, $\left.\mathrm{CHCl}_{3}\right)$; IR (KBr) $v_{\max } 3478$ (broad) and $1732 \mathrm{~cm}^{-1}$; ${ }^{1} \mathrm{H}$ and ${ }^{13} \mathrm{C}$ NMR data, see Tables 1 and 3; ESIMS $m / z$ z 635 [100, (M $+\mathrm{Na})^{+}$], 381 (21); HRESIMS $m / z, 635.3409$ (calcd for $\mathrm{C}_{32} \mathrm{H}_{52} \mathrm{O}_{11} \mathrm{Na}$, 635.3407).

Simplexin D (4): colorless oil (10.1 mg); $[\alpha]_{\mathrm{D}}^{26}+9.0\left(c 1.0, \mathrm{CHCl}_{3}\right)$; IR (neat) $v_{\max } 3489$ (broad) and $1732 \mathrm{~cm}^{-1} ;{ }^{1} \mathrm{H}$ and ${ }^{13} \mathrm{C}$ NMR data, see
Tables 1 and 3; ESIMS $\mathrm{m} / z 663$ [100, $(\mathrm{M}+\mathrm{Na})^{+}$]; HRESIMS $\mathrm{m} / z$, 663.3718 (calcd for $\mathrm{C}_{34} \mathrm{H}_{56} \mathrm{O}_{11} \mathrm{Na}, 663.3720$ ).

Simplexin E (5): colorless oil (10.4 mg); $[\alpha]_{\mathrm{D}}^{26}+14.0\left(\right.$ c 2.3, $\left.\mathrm{CHCl}_{3}\right)$; IR (neat) $v_{\max } 3478$ (broad), 1733 and $1636 \mathrm{~cm}^{-1}$; UV (MeOH) $\lambda_{\max }$ $216(\log \varepsilon=3.50) ;{ }^{1} \mathrm{H}$ and ${ }^{13} \mathrm{C}$ NMR data, see Tables 1 and 3; ESIMS $\mathrm{m} / \mathrm{z} 647\left[100,(\mathrm{M}+\mathrm{Na})^{+}\right]$; HRESIMS m/z, $647.3410[\mathrm{M}+\mathrm{Na}]^{+}(\mathrm{calcd}$ for $\left.\mathrm{C}_{33} \mathrm{H}_{52} \mathrm{O}_{11} \mathrm{Na}, 647.3407\right)$.

Simplexin F (6): white powder (9.6 mg); mp $113.0-113.5^{\circ} \mathrm{C} ;[\alpha]_{\mathrm{D}}^{26}$ +18.1 ( c 2.68, $\mathrm{CHCl}_{3}$ ); IR (neat) $v_{\max } 3450$ (broad) and $1728 \mathrm{~cm}^{-1}$; ${ }^{1} \mathrm{H}$ and ${ }^{13} \mathrm{C}$ NMR data, see Tables 1 and 4; ESIMS $\mathrm{m} / \mathrm{z} 565[100$, (M $+\mathrm{Na})^{+}$]; HRESIMS $m / z$ 565.2987 (calcd for $\mathrm{C}_{28} \mathrm{H}_{46} \mathrm{O}_{10} \mathrm{Na}, 565.2989$ ).

Simplexin G (7): white powder $(1.6 \mathrm{mg}) ; \mathrm{mp} 101.5-102.5^{\circ} \mathrm{C} ;[\alpha]_{\mathrm{D}}^{26}$ $+34\left(\right.$ c $\left.0.4, \mathrm{CHCl}_{3}\right)$; IR (neat) $v_{\max } 3451$ (broad) and $1734 \mathrm{~cm}^{-1} ;{ }^{1} \mathrm{H}$ and ${ }^{13} \mathrm{C}$ NMR data, see Tables 2 and 4; ESIMS m/z $565[100,(\mathrm{M}+$ $\mathrm{Na})^{+}$]; HRESIMS $\mathrm{m} / z$ 565.2991 (calcd for $\mathrm{C}_{28} \mathrm{H}_{46} \mathrm{O}_{10} \mathrm{Na}, 565.2989$ ).

Simplexin H (8): white powder $(2.8 \mathrm{mg}) ; \mathrm{mp} 88.0-89.0{ }^{\circ} \mathrm{C} ;[\alpha]_{\mathrm{D}}^{26}$ $+30\left(\right.$ c 0.6, $\left.\mathrm{CHCl}_{3}\right)$; IR (neat) $v_{\max } 3449$ (broad) and $1730 \mathrm{~cm}^{-1} ;{ }^{1} \mathrm{H}$ and ${ }^{13} \mathrm{C}$ NMR data, see Tables 2 and 4; ESIMS $\mathrm{m} / z$, 549 [100, $(\mathrm{M}+$ $\mathrm{Na})^{+}$], 467 (16); HRESIMS $\mathrm{m} / z, 549.3042$ (calcd for $\mathrm{C}_{28} \mathrm{H}_{46} \mathrm{O}_{9} \mathrm{Na}$, 549.3039).

Simplexin I (9): white powder $(8.0 \mathrm{mg}) ; \mathrm{mp} 85.5-86.0^{\circ} \mathrm{C} ;[\alpha]_{\mathrm{D}}^{26}$ +28.6 (c 1.5, $\mathrm{CHCl}_{3}$ ); IR (neat) $v_{\max } 3452$ (broad) and $1728 \mathrm{~cm}^{-1} ;{ }^{1} \mathrm{H}$ and ${ }^{13} \mathrm{C}$ NMR data, see Tables 2 and 4; ESIMS $\mathrm{m} / z$. 521 [100, (M + $\mathrm{Na})^{+}$], 439 (23), 381 (37), 353 (11); HRESIMS m/z 521.2727 (calcd for $\mathrm{C}_{26} \mathrm{H}_{42} \mathrm{O}_{9} \mathrm{Na}$, 521.2726).

Preparation of $(S)$ - and $(R)$-MTPA Esters of 1. To a solution of $1(2.0 \mathrm{mg})$ in pyridine $(100 \mu \mathrm{L})$ was added $R$ - $(-)-\alpha$-methoxy- $\alpha-$ (trifluoromethyl)phenylacetyl chloride $(10 \mu \mathrm{L})$, and the solution was allowed to stand overnight at room temperature. The reaction mixture was added to $1.0 \mathrm{~mL}$ of $\mathrm{H}_{2} \mathrm{O}$, followed by extraction with EtOAc (1.0 $\mathrm{mL} \times 3$ ). The EtOAc-soluble layers were combined, dried over anhydrous $\mathrm{MgSO}_{4}$, and evaporated. The residue was purified by a short silica gel column using acetone $-n$-hexane (1:6) to yield the $(S)$-MTPA ester 1a $(1.2 \mathrm{mg})$. The same procedure was applied to obtain the $(R)$ MTPA ester $1 \mathbf{b}(0.8 \mathrm{mg})$ from the reaction of $S$ - $(+)-\alpha$-methoxy- $\alpha$ (trifluoromethyl)phenylacetyl chloride with 1. Selected ${ }^{1} \mathrm{H}$ NMR $\left(\mathrm{CDCl}_{3}, 400 \mathrm{MHz}\right)$ data of 1a: $\delta 5.414(1 \mathrm{H}, \mathrm{s}, \mathrm{H}-16 \mathrm{a}), 5.388(1 \mathrm{H}, \mathrm{d}$, $J=3.2 \mathrm{~Hz}, \mathrm{H}-6), 5.303$ (1H, s, H-16b), 4.109 (1H, dd, $J=10.6,5.2$ $\mathrm{Hz}, \mathrm{H}-9), 3.146(1 \mathrm{H}, \mathrm{dd}, J=14.0,5.2 \mathrm{~Hz}, \mathrm{H}-8), 2.526(1 \mathrm{H}, \mathrm{d}, J=$ $14.0 \mathrm{~Hz}, \mathrm{H}-8), 2.179$ (1H, m, H-4a), 2.026 (1H, m, H-5a), 1.895 (1H, m, H-5b), 1.854 (1H, m, H-4b), 1.524 (3H, s, Me-15). Selected ${ }^{1} \mathrm{H}$ 

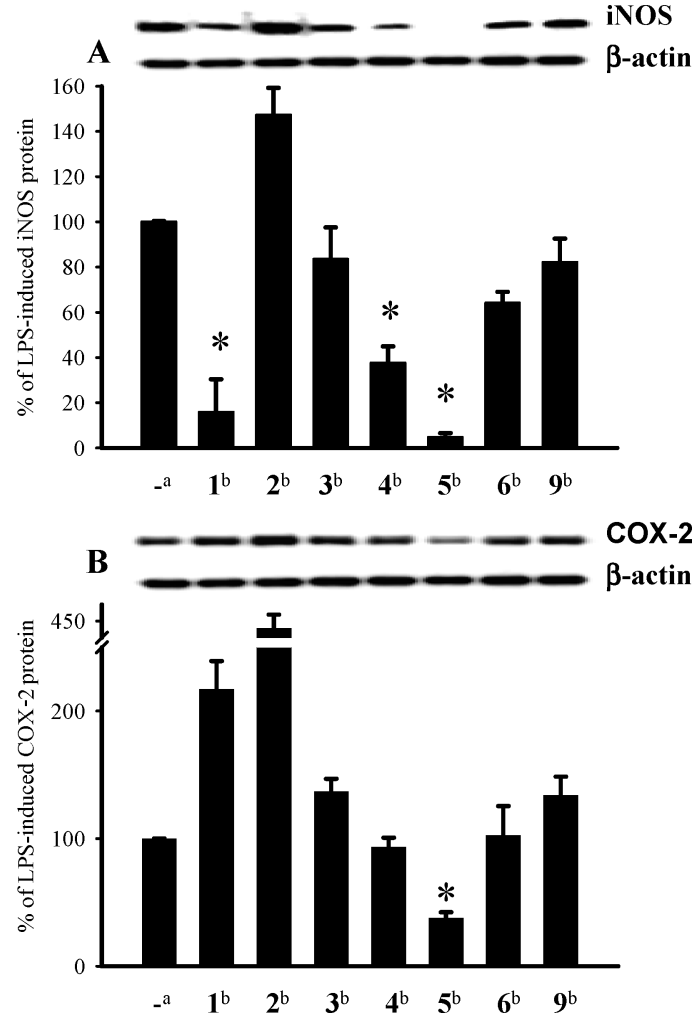

Figure 4. Effect of compounds $\mathbf{1}-\mathbf{6}$ and $\mathbf{9}$ on iNOS and COX-2 protein expression of RAW264.7 macrophage cells by immunoblot analysis. (A) Immunoblots of iNOS and $\beta$-Actin; (B) immunoblots of $\mathrm{COX}-2$ and $\beta$-actin. The values are mean $\pm \operatorname{SEM}(n=6)$. Relative intensity of the LPS alone stimulated group was taken as $100 \%$. Under the same experimental conditions CAPE (caffeic acid phenylethyl ester, $10 \mu \mathrm{M}$ ) reduced the levels of the iNOS and COX-2 to $2.5 \pm 3.7 \%$ and $67.2 \pm 13.4 \%$, respectively. *Significantly different from LPS alone stimulated group $(* P<0.05)$. ${ }^{a}$ Stimulated with LPS. ${ }^{b}$ Stimulated with LPS in the presence of $\mathbf{1 - 6}$ and $9(10 \mu \mathrm{M})$.

NMR $\left(\mathrm{CDCl}_{3}, 400 \mathrm{MHz}\right)$ data of $\mathbf{1 b}: \delta 5.366(1 \mathrm{H}, \mathrm{dd}, J=13.6,3.6$ Hz, H-6), 5.206 (1H, s, H-16a), 5.198 (1H, s, H-16b), 4.100 (1H, dd, $J=10.6,5.2 \mathrm{~Hz}, \mathrm{H}-9), 3.184(1 \mathrm{H}, \mathrm{dd}, J=13.6,5.2 \mathrm{~Hz}, \mathrm{H}-8), 2.509$ $(1 \mathrm{H}, \mathrm{d}, J=13.6 \mathrm{~Hz}, \mathrm{H}-8), 2.189$ (1H, m, H-4a), 2.100 (1H, m, H-5a), $1.900(1 \mathrm{H}, \mathrm{m}, \mathrm{H}-5 \mathrm{~b}), 1.870(1 \mathrm{H}, \mathrm{m}, \mathrm{H}-4 \mathrm{~b}), 1.536$ (3H, s, Me-15).
Cytotoxicity Testing. Cell lines were purchased from the American Type Culture Collection (ATCC). Cytotoxicity assays of compounds 1-6 and 9 were performed using the MTT [3-(4,5-dimethylthiazole2-yl)-2,5-diphenyltetrazolium bromide] colorimetric method. ${ }^{16,17}$

In Vitro Anti-inflammatory Assay. Assay procedure was as previously reported. ${ }^{18}$

Acknowledgment. Financial support was provided by Ministry of Education (96C031702) and National Science Council of Taiwan (NSC 95-2113-M-110-011-MY3) awarded to J.-H.S.

Supporting Information Available: The ${ }^{1} \mathrm{H}$ and ${ }^{13} \mathrm{C}$ NMR spectra of 1-9 are available free of charge via the Internet at http://pubs.acs.org.

\section{References and Notes}

(1) Kennard, O.; Watson, D. G.; Riva di Sanseverino, L.; Tursch, B.; Bosmans, R.; Djerassi, C. Tetrahedron Lett. 1968, 24, 2879-2884.

(2) Lin, Y.; Bewely, C. A.; Faulkner, D. J. Tetrahedron 1993, 49, 79777984.

(3) Chill, L.; Berrer, N.; Benayahu, Y.; Kashman, Y. J. Nat. Prod. 2005, $68,19-25$.

(4) Ahmed, A. F.; Wu, M.-H.; Wang, G.-H.; Wu, Y.-C.; Sheu, J.-H. J. Nat. Prod. 2005, 68, 1051-1055.

(5) Chen, S.-P.; Sung, P.-J.; Duh, C.-Y.; Dai, C.-F.; Sheu, J.-H. J. Nat. Prod. 2001, 64, 1241-1242.

(6) Kakonikos, C.; Vagias, C.; Roussis, V. Nat. Prod. Lett. 1999, 13, 8995.

(7) Ortega, M. J.; Zubia, E.; Salva, J. J. Nat. Prod. 1994, 57, 1584-1586.

(8) Su, J.-H.; Huang, H.-C.; Chao, C.-H.; Yan, L.-Y.; Wu, Y.-C.; Wu, C.-C.; Sheu, J.-H. Bull. Chem. Soc. Jpn. 2005, 78, 877-879.

(9) Sharma, P.; Alam, M. J. Chem. Soc., Perkin Trans. 1 1988, 25372540.

(10) Wang, G.-H.; Sheu, J.-H.; Duh, C.-Y.; Chiang, M. Y. J. Nat. Prod. 2002, 65, 1475-1478.

(11) Fusetani, N.; Nagata, H.; Hirota, H.; Tsuyuki, T. Tetrahedron Lett. 1989, 30, 7079-7082.

(12) Miyamoto, T.; Yamada, K.; Ikeda, N. J. Nat. Prod. 1994, 57, 12121219.

(13) Ospina, C. A.; Rodriguez, A. D. J. Nat. Prod. 2006, 69, 1721-1727.

(14) Wang, G.-H.; Sheu, J.-H.; Chiang, M. Y.; Lee, T.-J. Tetrahedron Lett. 2001, 42, 2333-2336.

(15) Ohtani, I.; Kusumi, T.; Kashman, Y.; Kakisawa, H. J. Am. Chem. Soc. 1991, 113, 4092-4096.

(16) Alley, M. C.; Scudiero, D. A.; Monks, A.; Hursey, M. L.; Czerwinski, M. J.; Fine, D. L.; Abbott, B. J.; Mayo, J. G.; Shoemaker, R. H.; Boyd, M. R. Cancer Res. 1988, 48, 589-601.

(17) Scudiero, D. A.; Shoemaker, R. H.; Paull, K. D.; Monks, A.; Tierney, S.; Nofziger, T. H.; Currens, M. J.; Seniff, D.; Boyd, M. R. Cancer Res. 1988, 48, 4827-4833.

(18) Lu, Y.; Huang, C.-Y.; Lin, Y.-F.; Wen, Z.-H.; Su, J.-H.; Kuo, Y.-H.; Chiang, M. Y.; Sheu, J.-H. J. Nat. Prod. 2008, 71, 1754-1759.

NP900064A 